\title{
High Concentration of Somatostatin Immunoreactivity in Chicken Pancreas
}

\author{
G. C. Weir, P.C. Goltsos, E.P. Steinberg and Y.C. Patel \\ Diabetes Unit of Massachusetts General Hospital, and Endocrine Division, Tufts-New England Medical Center Hospital, \\ Boston, Massachusetts USA
}

Summary. Extracts of discrete lobes of chicken pancreas were assayed for somatostatin (SRIF), insulin, and glucagon immunoreactivity. The distribution of hormone concentration was correlated appropriately with the known distribution of $\mathrm{A}, \mathrm{B}$, and $\mathrm{D}$-cells. Concentrations of all three hormones were highest in the splenic lobe. The glucagon content of the ventral and dorsal lobes was low. Evidence is presented that the SRIF-like material in the pancreatic extracts is very similar to synthetic cyclic SRIF; parallel immunoassay displacement curves and similar chromatographic elution profiles were obtained. The SRIF concentration in chicken pancreas is 21 times higher than that found in the rat. Chicken pancreas may provide a useful model for studies of somatostatin physiology.

Key words: Chicken pancreas, somatostatin, insulin, glucagon.

Somatostatin (SRIF) is a cyclic fourteen amino acid peptide originally isolated from the hypothalamus [1]. In addition to inhibiting growth hormone secretion it has also been found to inhibit the release of insulin, glucagon, gastrin, secretin, ACTH, prolactin and TSH [2-7]. Furthermore it is capable of inhibiting gastric acid [3] and pancreatic exocrine secretion $[7,8,9]$.

The presence of somatostatin in extraneural tissues was first suggested by Dubois who demonstrated somatostatin immunoreactivity in pancreatic islets of mammals and birds by immunofluorescence techniques [10]. Somatostatin immunoreactivity was also found in extracts of rat islets [11] and of whole pancreas [12] using specific radioimmunoassays. Furthermore the gel filtration elution profiles of the rat islet extracts were identical to those of synthetic cyclic somatostatin (unpublished observations of Patel, Reichlin and Weir). Somatostatin immunoreactivity has also been found in gastrointestinal tissue [12 and unpublished observations of Patel, Reichlin and Weir]. The cell of origin of somatostatin in both the pancreas and gut appears to be the D-cell [13]. Because of the large number of D-cells in the avian pancreas it was decided to evaluate the somatostatin content of the chicken pancreas.

\section{Materials and Methods}

Five-week old White Leghorn chickens were sacrificed and individual pancreatic lobes (ventral, dorsal, third, and splenic) were dissected out, weighed, and placed in iced Hanks solution. As soon as possible they were individually homogenized with a Ten Broeck pyrex homogenizer in $5 \mathrm{ml}$ of $2 \mathrm{~N}$ acetic acid. Tubes containing these homogenates were then suspended in boiling water for five minutes to inactivate proteolytic pancreatic enzymes and the extracts frozen pending assay. Before dilution for assay aliquots of the extracts were neutralized with $\mathrm{NaOH}$.

The radioimmunoassay for somatostatin (method of Patel, and Reichlin, unpublished) utilized a rabbit antiserum obtained following immunization with SRIF conjugated to thyroglobulin. This antiserum was highly specific for SRIF with negligible or no crossreactivity with insulin, glucagon, gastrin, cholecystokinin-pancreozymin, cholecystokinin octapeptide (C8-CCK), secretin, vasoactive peptide (VIP), substance $P$ and neurotensin. $\left[{ }^{125} \mathrm{I}\right]$ Tyr ${ }_{1}$-SRIF was iodinated with chloramine T. Synthetic cyclic somatostatin (kindly provided by the Ayerst Company, Montreal, Canada) was used as standard. The buffered diluent was $0.05 \mathrm{M} \mathrm{PO}_{4}$ with $0.1 \%$ crystalline BSA at 
a $\mathrm{pH}$ 7.5. The incubation volume was $0.7 \mathrm{ml}$ and dextran-charcoal separation was employed [14]. The detection limit for the assays done in this study was 3-4 pg of SRIF per incubation tube.

Glucagon concentrations were determined with radioimmunoassay methods previously described [15] utilizing antiserum $30 \mathrm{~K}$ provided by Dr. Roger Unger. Pork glucagon (lot GLF 599A, Eli Lilly and Company) was used as standard. The insulin radioimmunoassay method was that of Albano et al. [16] and chicken insulin (lot 615-1082B-249) was kindly donated by Dr. Ronald Chance of Eli Lilly and Company.

\section{Results}

The hormone concentration of individual lobes of the chicken pancreas is presented in Table 1 . The concentration of all three hormones is greatest in the splenic lobe, with the glucagon concentration being strikingly high. It is noteworthy that the glucagon concentration of the ventral and dorsal lobes is very low. When the total hormonal content of each lobe is determined (Table 2) it can be appreciated that the splenic lobe contributes little to total amount of insulin or SRIF, but contains at least half of the total

Table 1. Hormone concentration of chicken pancreas (ng/mg)

\begin{tabular}{lrrrrr}
\hline $\begin{array}{l}\text { Pancreatic } \\
\text { Lobe (n) }\end{array}$ & \multicolumn{1}{c}{ Insulin } & Glucagon & \multicolumn{2}{l}{ SRIF } \\
\hline Ventral [6] & $40.9 \pm 7.1$ & $1.12 \pm$ & 0.30 & $3.40 \pm 0.85$ \\
Dorsal [6] & $22.7 \pm 3.1$ & $0.55 \pm$ & 0.11 & $3.07 \pm 0.63$ \\
Third [5] & $55.1 \pm 9.1$ & $13.9 \pm$ & 3.7 & $9.23 \pm 1.64$ \\
Splenic [6] & $171.0 \pm 26.6$ & $599.0 \pm 128.0$ & $22.63 \pm 5.51$ \\
Total & & & & & \\
Pancreas [5] & $33.6 \pm 4.0$ & $8.16 \pm$ & 1.43 & $3.76 \pm 0.80$ \\
\hline
\end{tabular}

a Calculations could only be made for five total pancreata because a third lobe from one of the six chickens was lost.

Table 2. Hormone content of chicken pancreas

\begin{tabular}{lrrrr}
\hline $\begin{array}{l}\text { Pancreatic } \\
\text { Lobe }(\mathrm{n})\end{array}$ & \multicolumn{2}{l}{$\begin{array}{l}\text { Lobe } \\
\text { Weight }(\mathrm{mg})\end{array}$} & Insulin $(\mu \mathrm{g})$ & Glucagon $(\mu \mathrm{g})$ SRIF $(\mu \mathrm{g})$ \\
\hline Ventral [6] & $274 \pm 24$ & $11.2 \pm 2.3$ & $0.30 \pm 0.10$ & $0.91 \pm 0.28$ \\
Dorsal [6] & $598 \pm 39$ & $13.6 \pm 2.3$ & $0.32 \pm 0.05$ & $1.82 \pm 0.40$ \\
Third [5] & $254 \pm 39$ & $12.6 \pm 0.9$ & $3.05 \pm 0.27$ & $2.19 \pm 0.39$ \\
Splenic [6] & $12 \pm 3$ & $1.8 \pm 0.3$ & $5.76 \pm 1.09$ & $0.23 \pm 0.07$ \\
\cline { 2 - 5 } & & & & \\
Total & & & & \\
Pancreas [5] & $1156 \pm 35$ & $38.6 \pm 4.2$ & $9.29 \pm 1.48$ & $4.33 \pm 0.90$
\end{tabular}

a Calculations could only be made for five total pancreata because a third lobe from one of the six chickens was lost. glucagon. The contribution of the splenic lobe may actually be slightly higher, because it was difficult to dissect out all of a given splenic lobe. Splenic lobes probably weigh about $20 \mathrm{mg}$ each and therefore the figure of $12 \pm 3 \mathrm{mg}$ is probably low. It was also difficult to accurately delineate the caudal border of the third lobe in some of the birds. Nonetheless we are confident that most, if not all, of what is called the third lobe, is in fact the third lobe. Even though there are definite differences in amount of each hormone as determined by weight there are less marked differences if the amounts are expressed in molar terms (insulin: $6.5 \mathrm{nM}$; glucagon: $3.2 \mathrm{nM}$; and SRIF: 3.7 $\mathrm{nM}$ ).

Further studies were done to help determine the likelihood that the material with SRIF-like immunoreactivity was SRIF. As shown in Fig. 1, when dilutions of a splenic lobe extract were assayed the inhibition curve was parallel to that of synthetic cyclic SRIF. The splenic lobe extract was also subjected to column chromatography (Fig. 2). The elution profile of SRIF immunoreactivity from the extract is almost identical to that of synthetic cyclic SRIF under identical conditions. In each case the major peak of immunoreactivity is preceded by a small peak close to the void volume fraction.

\section{Discussion}

The anatomy of the chicken endocrine pancreas differs markedly from that found in mammals. Two separate types of islets have been described. The so called light islets are composed of B- and D-cells, whereas dark islets consist primarily of A- and D-cells [17]. One study has found the cellular population of light islets to contain $14 \% \mathrm{D}$-cells whereas dark islets have $28 \%$ D-cells [17]. This contrasts with man and monkey in which D-cells occupy $10-15 \%$ of the islet cells and the rat which contains $4.4 \% \mathrm{D}$-cells [18]. Another feature of the chicken pancreas is that it consists of four lobes. The ventral and dorsal lobes contain almost exclusively light islets whereas the third and the small splenic lobe contain both light and dark islets. The study by Mikami and Ono [17] and unpublished morphological studies of ours indicate that a remarkably large proportion of the splenic lobe consists of endocrine tissue.

The hormonal distribution found in the present study correlates reasonably well with the anatomical arrangements described above. The largest concentrations of all three hormones are found in the splenic lobe. Furthermore the concentration of glucagon in the ventral and dorsal lobes was very low. The insulin concentration of the entire chicken pancreas approxi- 


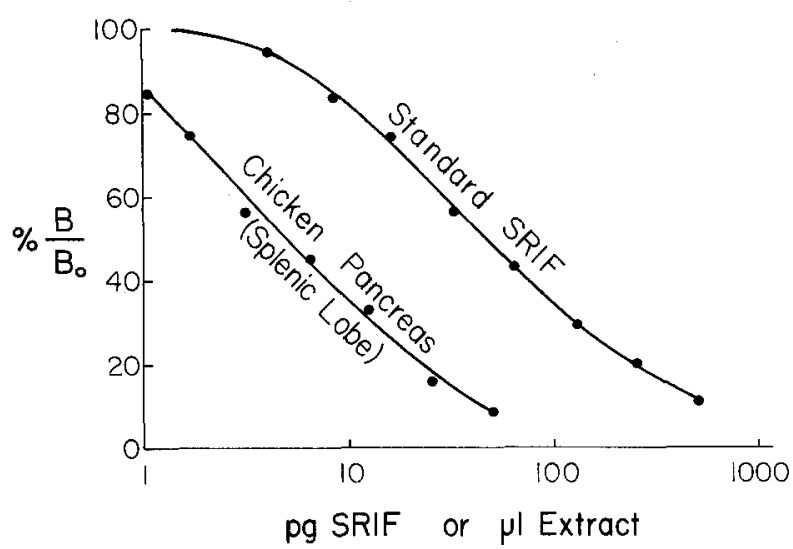

Fig. 1. Standard curve of synthetic cyclic somatostatin compared with inhibition curve produced by serial dilutions of an extract of the splenic lobe of chicken pancreas

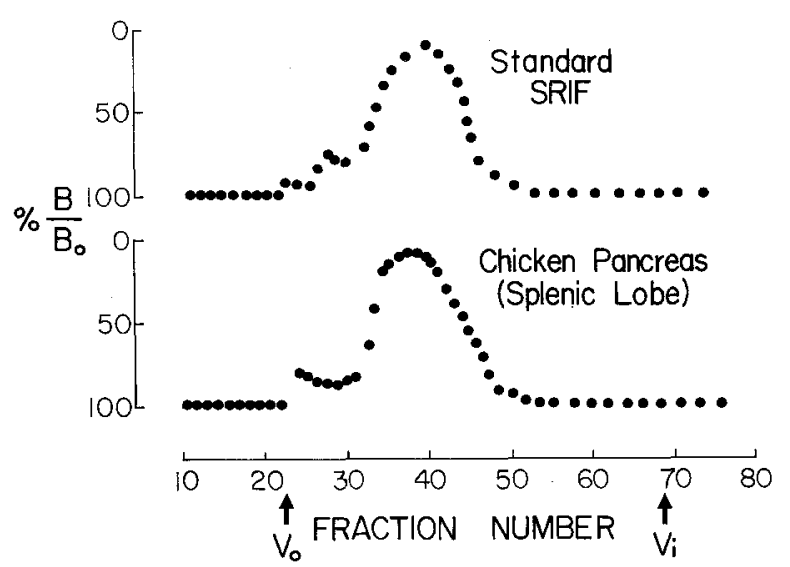

Fig. 2. Gel filtration elution patterns of synthetic cyclic somatostatin and an extract of the splenic lobe of chicken pancreas. A $1 \times 64 \mathrm{~cm}$ column contained Sephadex G-25 and was eluted with $1 \mathrm{M}$ urea $0.05 \mathrm{MPO}_{4}$ buffer, $\mathrm{pH}$ 7.5. 20 drop fractions were collected. Vo and Vi were determined using $\left[{ }^{125} \mathrm{I}\right]$ albumin and $\left[{ }^{125} \mathrm{I}\right]$ respectively

mates that found in an earlier study and is lower than the concentration found in a number of mammalian species [19]. Older studies indicate that chicken pancreas contains ten times more bioassayable glucagon than mammalian pancreas [20]. The glucagon content of the chicken pancreas in the present study $(8 \mathrm{ng} / \mathrm{mg})$ was similar to that found in rat $(5 \mathrm{ng} / \mathrm{mg})$ [21], bovine $(8 \mathrm{ng} / \mathrm{mg})$ and human $(9 \mathrm{ng} / \mathrm{mg})$ [22]. Some of this discrepancy may be due to differences of extraction and immunoassay technique.

The finding that the displacement curves of extracts of splenic lobes and synthetic cyclic somatostatin are parallel (Fig. 1) suggests that the immunological characteristics of the two substances are identical. This would also suggest that the structures of the two may be identical or very similar. Furthermore the similar elution profiles seen with column chromato- graphy (Fig. 2) would also suggest similarity. The identity of the small early peak is not known, but it may represent either a dimer of SRIF or a larger precursor form of the hormone. Further proof that this pancreatic material is somatostatin awaits peptide sequence determination and demonstration of biological activity. It is of interest that before the discovery of somatostatin Hellman and Lernmark demonstrated that an aqueous extract of pigeon D-cells inhibited in vitro insulin secretion [23].

The content of somatostatin immunoreactivity is high in all four lobes of the chicken pancreas and is markedly higher than that found in extracts of rat pancreas. We have found the concentration in the pancreata of $450 \mathrm{~g}$ male Sprague-Dawley rats to be $0.18 \pm 0.02 \mathrm{ng} / \mathrm{mg}(\mathrm{n}=6)$ and Arimura et al. have reported a concentration of $0.14 \mathrm{ng} / \mathrm{mg}$ [11]. Orci et al. have recently indicated that the number of cells in the pigeon pancreas with somatostatin-like immunofluorescence is greater than is found in rat, dog, pig and man [24]. The function of SRIF in the chicken pancreas is unknown. The finding of these high concentrations suggests that the chicken pancreas may be an excellent model for studies of the secretion and biosynthesis of pancreatic somatostatin.

Acknowledgement. This work was supported by grants from NIH (AM18230 and No. 16684) and by the C.J. Martin Fellowship of the N.H. and M.R.C. Australia (Dr. Patel).

\section{References}

1. Brazeau, R., Vale, W., Burgus, R., Ling, N., Butcher, M., Rivier, J., Guillemin, R.: Hypothalamic polypeptide that inhibits the secretion of immunoreactive growth hormone. Science 179, 77-79 (1973)

2. Koerker, D. J., Ruch, W., Chideckel, E., Palmer, J., Goodner, C., Ensinck, J., Gale, C.C.: Somatostatin: Hypothalamic inhibitor of the endocrine pancreas. Science 184, 482-484 (1974)

3. Bloom, S. R., Mortimer, C.H., Thorner, M.O., Besser, G. M., Hall, R., Gomez-Pan, A., Roy, V.M., Russell, R.C.A., Coy, D.H., Kastin, A.J., Schally, A.V.: Inhibition of gastrin and gastric-acid secretion. Lancet 1974 II, 1106-1109

4. Siler, T.N., Vandenberg, A., Yen, S. S. C.: Inhibition of growth hormone release in humans by somatostatin. J. clin. Endocr. 37, 632-634 (1973)

5. Tyrrell, J.B., Lorenzi, M., Gerich, J.E., Forsham, P.H.: Inhibition by somatostatin of ACTH secretion in Nelson's syndrome. J. clin. Endocr. 40, 1125-1127 (1975)

6. Vale, W., Rivier, C., Brazeau, P., Guillemin, R.: Effects of somatostatin on the secretion of thyrotropin and prolactin. Endocrinology 95, 968-977 (1974)

7. Creutzfeldt, W., Lankisch, P.G., Fölsch, U.R.: Hemmung der Sekretin- und Cholezystokinin-Pankreozymin-induzierten Saft- und Enzymsekretion des Pankreas und der Gallenblasenkontraktion beim Menschen durch Somatostatin. Dtsch. med. Wschr. 100, 1135-1138 (1975) 
8. Lankisch, P.G., Arnold, R., Creutzfeldt, W.: Wirkung von Somatostatin auf die betazol-stimulierte Magensekretion und die carbachol-stimulierte Pankreassekretion und Gallenblasenkontraktion des Menschen. Dtsch. med. Wschr. 100, 1797-1800 (1975)

9. Boden, G., Sivitz, M. C., Owen, O. E., Essa-Koumar, N., Landor, J.M.: Somatostatin suppresses secretin and pancreatic exocrine secretion. Science 190, 163-164 (1975)

10. Dubois, M.P.: Presence of immunoreactive somatostatin in discrete cells of the endocrine pancreas. Proc. nat. Acad. Sci. (Wash.) 72, 1340-1343 (1975)

11. Patel, Y.C., Weir, G.C., Reichlin, S.: Anatomic distribution of somatostatin in brain and pancreatic islets as studied by radioimmunoassay. Program of the 57th Meeting, p. 127 American Endocrine Society 1975

12. Arimura, A., Sato, H., Dupont, A., Nishi, N., Shally, A.V.: Somatostatin: Abundance of immunoreactive hormone in rat stomach and pancreas. Science 189, 1007-1009 (1975)

13. Polak, J.M., Pearse, A.G.E., Grimelius, L., Bloom, S.R., Arimura, A.: Growth-hormone release-inhibiting hormone in gastrointestinal and paricreatic D-cells. Lancet 1975 I, $1220-1222$

14. Arimura, A., Sato, H., Coy, D.H., Schally, A.V.: Radioimmunoassay for GH-release inhibiting hormone. Proc. Soc. exp. Biol. (N.Y.) 148, 784-793 (1975)

15. Weir, G. C., Knowlton, S. D., Martin, D. B.: Glucagon secretion from the perfused rat pancreas. J. clin. Invest. 54, 1403-1412 (1974)

16. Albano, J.D.M., Ekins, R.P., Maritz, G., Turner, R.C.: A sensitive precise radioimmunoassay of serum insulin relying on charcoal separation of bound and free hormone moieties. Acta endocr. 70, 487-509 (1972)

17. Mikami, S.I., Ono, K.: Glucagon deficiency induced by extirpation of alpha islets of the fowl pancreas. Endocrinology 71, $464-473$ (1962)
18. Fujita, T.: D-cell, the third endocrine element of the pancreatic islet. Arch. histol. jap. 29, 1-40 (1968)

19. Langslow, D. R., Kimmel, J.R., Pollock, H.G.: Studies of the distribution of a new avian pancreatic polypeptide and insulin among birds, reptiles, amphibians and mammals. Endocrinology 93, 558-565 (1973)

20. Falkmer, S., Marques, M.: In: Glucagon, molecular physiology, clinical, and therapeutic implications. p. 347. New York: Pergamon Press 1972

21. Pagliara, A.S., Stillings, S.N., Haymond, M.W., Hover, B. A., Matschinsky, F.M.: Insulin and glucose as modulators of the amino acid induced glucagon release in the isolated pancreas of alloxan and streptozotocin diabetic rats. J. clin. Invest. 55, 244-255 (1975)

22. Unger, R.H.: In: Glucagon, molecular physiology, clinical, and therapeutic implications. p. 205. New York: Pergamon Press 1972

23. Hellman, B., Lernmark, A.: A possible role of the pancreatic $\alpha$ 1 - and $\alpha 2$-cells as local regulators of insulin secretion. In: Structure and metabolism of the pancreatic islets (eds. S. Falkmer, B. Hellman, I.-B. Täljedal), pp. 453-462. New York: Pergamon Press 1970

24. Orci, L., Baetens, D., Dubois, M.P., Rufener, C.: Evidence for the D-cell of the pancreas secreting somatostatin. Horm. Metab. Res. 7, 400-402 (1975)

Received: December 11, 1975, and in revised form: January 21, 1976

G.C. Weir, M.D.

Massachusetts General Hospital

Diabetes Unit

Boston, MA 02114

USA 